\title{
The Competence Development of Vocational High School Teachers Using The "ANAK SALA" Model
}

\author{
Sudarno', Suyanto ${ }^{2}$, Udik Budi Wibowo ${ }^{3}$ \\ ${ }^{1}$ Universitas Sebelas Maret, ${ }^{2,3}$ Universitas Negeri Yogyakarta \\ sudarno251168@gmail.com
}

\section{Article History}

accepted 31/01/2021

approved 28/02/2021

published 31/03/2021

\begin{abstract}
The purpose of this research is to develop the competence of vocational high school teachers in Karanganyar Regency, especially in the pedagogical competence, professional competence, personality competence, and social competence by using a development model named "ANAK SALA". This study uses the Research and Development method. The sample used was 50 vocational high school teachers. The data collection method used a questionnaire technique. The data that has been collected, then analyzed comprehensively using the mean difference test and descriptive-analysis. In conclusion, the competence development of vocational high school teachers in Karanganyar Regency, Central Java can effectively be carried out using the "ANAK SALA" model.
\end{abstract}

Keywords: competence, pedagogic, professional, personality, social

\begin{abstract}
Abstrak
Tujuan dari penelitian ini adalah melakukan pengembangan kompetensi guru-guru SMK di Kabupaten Karanganyar, khususnya kompetensi pedagogik, kompetensi profesional, kompetensi kepribadian, dan kompetensi sosial dengan menggunakan model hasil pengembangan yang diberi nama model "ANAK SALA". Penelitian ini menggunakan metode Research and Development. Sampel yang digunakan adalah sebanyak 50 orang guru SMK. Metode pengumpulan datanya menggunakan teknik angket. Data yang telah dikumpulkan, selanjutnya dianalisis secara komprehensif menggunakan uji beda mean dan bersifat deskriptifanalisis. Kesimpulannya, pengembangan kompetensi guru SMK di Kabupaten Karanganyar Jawa Tengah secara efektif dapat dilakukan menggunakan model "ANAK SALA".

Kata Kunci: kompetensi, pedagogik, profesional, kepribadian, sosial
\end{abstract}

Social, Humanities, and Education Studies (SHEs): Conference Series https://jurnal.uns.ac.id/shes

p-ISSN 2620-9284

e-ISSN 2620-9292

This work is licensed under a Creative Commons Attribution-ShareAlike 4.0 International License. 


\section{PENDAHULUAN}

Saat ini dunia sedang dihadapkan pada era revolusi industri ke 4, maupun era disruption dengan ditandai munculnya berbagai inovasi digital yang membuat segalanya menjadi mudah. (Alqiawi \& Ezzeldin, 2015) Perkembangan teknologi yang semakin canggih ini menjadikan dunia mengalami perubahan sangat cepat. Apabila seseorang tidak siap mengikuti perkembangan teknologi, maka mereka akan tertinggal oleh perubahan yang ditimbulkan oleh adanya perkembangan teknologi tersebut.

Di masa depan, banyak pekerjaan yang lebih mengedepankan pada pemanfaatan teknologi sehingga diperlukan sumber daya manusia yang terampil menggunakan teknologi. Hal ini merupakan sebuah tantangan bagi Sekolah Menengah Kejuruan (SMK) sebagai lembaga pendidikan kejuruan beserta gurunya untuk bisa menghasilkan sumber daya manusia yang terampil dan siap kerja. Pada kenyataannya, Badan Pusat Statistik (BPS) mencatat terjadinya peningkatan jumlah pengangguran untuk angkatan kerja dengan pendidikan terakhir SMK. Tren kenaikan terus terjadi dari tahun 2014 hingga tahun 2016. Pada tahun 2016, jumlah pengangguran dari kategori itu mencapai 1,3 juta orang. jumlah tersebut naik dibandingkan tahun sebelumnya yang mencapai 1,1 juta orang angkatan kerja (Solo Pos, Jum'at Legi 10 Februari 2017). Secara lebih detail jumlah pengangguran angkatan kerja lulusan SMK sebagai berikut. Tahun 2012 sebanyak 1.000.000 orang, tahun 2013 sebanyak 864.649 orang, tahun 2014 sebanyak 847.365 orang, tahun 2015 sebanyak 1.170.000, dan tahun 2016 sebanyak 1.340 .000 orang. Lebih lanjut (Surya Dharma, 2013) mencatat adanya perubahan-perubahan di masyarakat saat ini yang sekaligus juga merupakan tantangan bagi guru SMK, yaitu: (1) changes in the work place; (2) advances in digital technologies; (3) global connections; dan (4) changes in our understanding of learning.

Berdasarkan perkembangan perubahan yang terjadi di masyarakat tersebut, (Xu \& Ye, 2014) guru yang berkompeten benar-benar sangat dibutuhkan. Apabila guru tidak memiliki kompetensi yang baik, maka peserta didik yang diajar pun akan memiliki kompetensi yang tidak baik pula. Begitu juga guru SMK, harus memiliki kompetensi tentang penguasaan keterampilan yang diajarkannya. Guru SMK akan menghadapi banyak tantangan di masa depan. (Bhargava \& Pathy, 2011) Tantangan guru SMK diprediksi dari arah kebijakan pemerintah maupun arah perkembangan ilmu pengetahuan dan teknologi yang berdampak pada pengembangan SMK dan guru SMK. Pemerintah mengambil kebijakan untuk memberdayakan SMK dalam pembangunan ekonomi global yang tertuang dalam Rencana Pembangunan Pendidikan Nasional Jangka Panjang (RPPNJP), roadmap pengembangan SMK dari Direktorat Pembinaan SMK, MP3El (Master Plan Percepatan dan Perluasan Pembangunan Ekonomi Indonesia) dan rencana strategis Kementrian Perindustrian. Dalam RPPNJP, pemerintah mengharapkan agar SMK memiliki daya saing regional maupun internasional. Dalam roadmap pengembangan SMK, ke depan SMK diharapkan dapat menjadi kluster industri kecil dan menengah. Dari MP3EI, SMK memiliki peran sebagai penopang pembangunan ekonomi daerah di wilayahnya masing-masing, dan pada rencana strategis Kementerian Perindustrian, SMK diharapkan dapat menghasilkan lulusan yang mampu menjadi pengusaha di sektor industri kreatif. Data dari Direktorat Jenderal Guru dan Tenaga Kependidikan Jakarta, 7 November 2015 (Surya Dharma, 2013) tentang hasil UKA-UKG 2012-2014, menginformasikan bahwa hanya 192 orang dari total 1.611.251 orang guru yang memiliki skor 90-100. Lebih dari 1,3 juta orang guru memiliki skor di bawah 60 dari total skor 100 . 
Khusus guru SMK, dari total 119.334 orang guru SMK hasil UKA-UKG 2012-2014 terdistribusi sebagai berikut: skor/nilai 0-10 sebanyak 89 orang, skor 10,1-20 sebanyak 460 orang, skor 20,1-30 sebanyak 5.652 orang, skor 30,1-40 sebanyak 21,298 orang, skor 40,1-50 sebanyak 35,833 orang, skor 50,1-60 sebanyak 32.791 orang, skor $60,1-70$ sebanyak 17,469 orang, skor 70,1-80 sebanyak 5,072 orang, skor 80,1-90 sebanyak 654 orang, skor 90,1-100 sebanyak 16 orang (Hermanto \& Santika, 2016). Kenyataan ini menunjukkan apabila kompetensi guru SMK masih minimal dan perlu mendapatkan perhatian secara serius serta perlu peningkatan dan pengembangan secara berkelanjutan. Selain itu, ada pula guru-guru SMK yang belum tahu perkembangan teknologi yang dapat membantu mempermudah peserta didik memahami materi pembelajaran (Suyanto \& Asep Jihad, 2013)

Berdasarkan hasil survey pendahuluan ke beberapa guru SMK di Kabupaten Karanganyar Jawa Tengah, mereka menyatakan meskipun telah dilakukan upaya pengembangan terhadap kompetensi guru SMK namun pelaksanaannya belum dilakukan secara sistematis dan kurang efektif karena belum begitu memperhatikan kondisi kompetensi guru yang sebenarnya. Seperti halnya kesehatan tubuh manusia, kompetensi guru perlu pula untuk dilakukan check up melalui need assessment untuk mengetahui obat atau jenis terapi yang sesuai. Oleh karena itu sebelum dilakukan pembinaan dan pengembangan kompetensi guru SMK di Kabupaten Karanganyar, terlebih dahulu perlu dilakukan pemetaan kebutuhannya sehingga upaya pengembangan kompetensi yang akan dilakukan benar-benar sesuai dengan kebutuhan guru.

Di Kabupaten Karanganyar Jawa Tengah juga masih terdapat guru SMK yang kualifikasi pendidikannya belum S1. Berikut data secara lebih rinci yang diperoleh dari kantor Disdikpora Kabupaten Karanganyar Jawa Tengah mengenai kondisi guru SMK. Rangkuman data guru SMK negeri maupun swasta di Kabupaten Karanganyar Jawa Tengah Tahun Pelajaran 2014/2015 adalah sebagai berikut: guru SMK dengan ijazah tertinggi D2 sebanyak 2 orang, D3 sebanyak 32 orang, S1 sebanyak 596 orang, dan S2 sebanyak 55 orang. Data tersebut menunjukkan jika guru SMK di Kabupaten Karanganyar Jawa Tengah masih terdapat beberapa guru yang kualifikasi pendidikannya belum sesuai dengan standar yang dipersyaratkan dalam Undang-Undang Guru dan Dosen yakni minimal S1 atau D-IV.

Berdasarkan uraian di atas, maka dipandang perlu dan menarik untuk dilakukan penelitian tentang kompetensi guru-guru SMK di Kabupaten Karanganyar Jawa Tengah, terutama yang telah dinyatakan lulus sertifikasi (bersertifikat pendidik), apakah benarbenar telah memiliki kompetensi standar sesuai dengan Permendiknas Nomor 16 tahun 2007 ataukah belum? Selanjutnya, bagaimanakah model manajemen pengembangan kompetensi yang bisa diterapkan secara efektif mampu meningkatkan kompetensi guruguru SMK di Kabupaten Karanganyar Jawa Tengah?

Berdasarkan latar belakang masalah di atas, muncul beberapa masalah yang dapat diidentifikasikan sebagai berikut.

1. Saat ini masih terdapat guru SMK yang belum layak mengajar karena belum memenuhi kualifikasi pendidikan minimal dan kompetensi standar.

2. Ada sebagian guru SMK yang belum memiliki kompetensi terkait dengan teknologi yang digunakan di dunia usaha dan industri. 
SHEs: Conference Series 4 (3) (2021) 63- 72

3. Pengembangan kompetensi guru SMK di Kabupaten Karanganyar Jawa Tengah belum efektif.

4. Meskipun sudah ada model manajemen pengembangan kompetensi guru SMK di Kabupaten Karanganyar Jawa Tengah, namun belum berjalan secara efektif.

Mengacu pada permasalahan yang berhasil diidentifikasi di atas, permasalahan penelitian ini dirumuskan sebagai berikut: Bagaimanakah model manajemen pengembangan kompetensi guru SMK di Kabupaten Karanganyar-Jawa Tengah yang efektif? Adapun tujuan dari penelitian ini adalah menemukan model manajemen pengembangan kompetensi yang dapat diterapkan secara efektif mampu meningkatkan kompetensi guru-guru SMK di Kabupaten Karanganyar, Jawa Tengah.

\section{METODE}

Penelitian menggunakan model Research and Development $(R n D)$. Prosedur penelitian mengacu prosedur dari (Gall, M.D. \& Borg, 1983) yang termodifikasi, yaitu: 1) Information Collecting and Planning, 2) Develop Preliminary Form of Product, 3) Preliminary Field Testing, 4) Main Product Revision, 5) Main Field Testing, 6) Final Product Revision, 7) Dissemination dan Implementation.

Penelitian dilakukan di Sekolah Menengah Kejuruan (SMK) Kabupaten Karanganyar, Jawa Tengah. Sampel penelitian sebanyak 50 guru. Teknik pengumpulan data menggunakan metode angket. Adapun Teknik analisisnya adalah Uji beda mean menggunakan uji t-test.

Penelitian menggunakan desain eksperimen pretes-postes menggunakan kelompok kontrol subjek random atau Pretest-Posttest Control Group Design (Sugiyono, 2012); (Ali, 2011). Kegiatan pengembangan model, meliputi (1) Mendeskripsikan kompetensi guru SMK; (2) Mendeskripsikan kebutuhan atau kekurangan guru SMK; (3) Mendeskripsikan dan menetapkan model pengembangan kompetensi guru SMK yang telah dilakukan di Karanganyar; (4) Menyusun prototipe (model hipotetik) pengembangan kompetensi guru SMK; (5) Mengujicobakan prototipe hasil penelitian dalam lingkup terbatas; (6) Mengidentifikasi kekurangan/kelemahan prototipe yang telah dihasilkan; (7) Mengevaluasi dan menyempurnakan prototipe yang telah dihasilkan; (8) Mengujicobakan prototipe hasil penelitian dalam lingkup luas, dan (9) Mendiseminasikan model hasil penelitian ke guru-guru SMK di Kabupaten Karanganyar.

Data yang telah dikumpulkan, dianalisis secara komprehensif menggunakan uji beda mean. 


\section{SHEs: Conference Series 4 (3) (2021) $63-72$}

\section{HASIL DAN PEMBAHASAN}

\section{Model hasil pengembangan}

Setelah melakukan berbagai langkah komprehensif, peneliti berhasil merumuskan model untuk mengembangkan kompetensi guru SMK sebagaimana gambar 1 berikut.

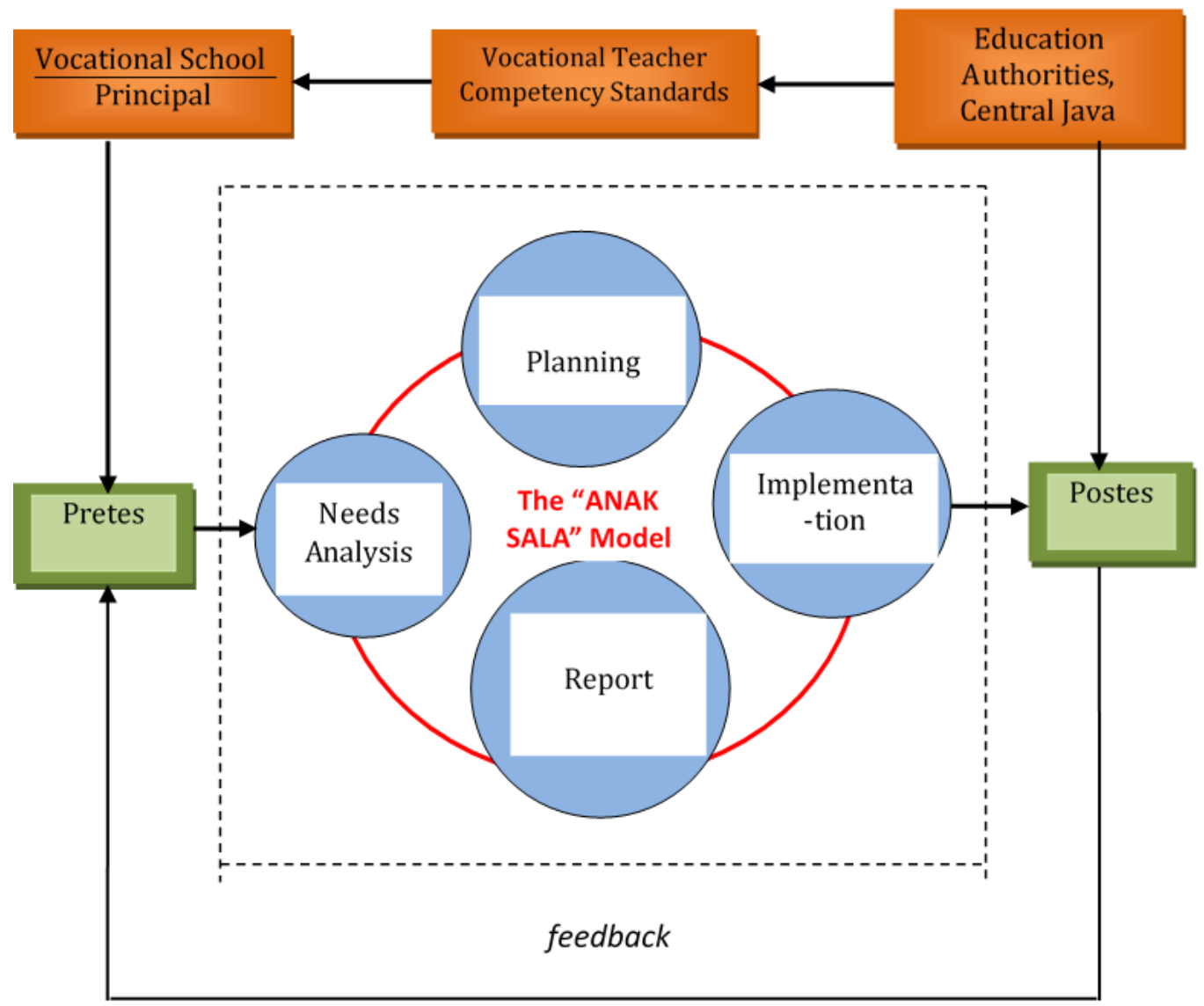

Gambar 1. Model yang Diimplementasikan

(Spencer, M.L. \& Spencer, 1993) 
SHEs: Conference Series 4 (3) (2021) $63-72$

\section{Pembahasan dampak model setelah implementasi}

Pengembangan kompetensi guru SMK model "ANAK SALA" ini telah diujicobakan terhadap 50 orang guru SMK di Kabupaten Karanganyar (25 orang guru sebagai kelompok kontrol, dan 25 orang guru sebagai kelompok eksperimen).

\section{Tabel 1. Skor Rata-rata Uji Kompetensi Guru SMK di Kabupaten Karanganyar}

\begin{tabular}{cccccc}
\hline Kelompok & Responden & Skor Pretest & Skor Posttest & Selisih & Keterangan \\
\hline Eksperimen & 25 & 172.056 & 183.872 & 11.816 & Meningkat \\
Kontrol & 25 & 174.568 & 178.576 & 4.008 & Meningkat \\
\hline
\end{tabular}

Setelah dilakukan uji beda mean menggunakan uji t-test selisih skor pretest posttest antara kelompok eksperimen dengan kelompok kontrol data pada tabel 1 , diperoleh nilai t hitung sebesar 7,121 dan signifikansi sebesar 0,000 . Oleh karena nilai $t$ hitung lebih besar dari nilai t tabel $(7,121>2,064)$ dan signifikansi $0,000<0,050$ maka Ho ditolak, sehingga disimpulkan bahwa terdapat perbedaan signifikan selisih skor pretest dengan posttest antara kelompok eksperimen dengan kelompok kontrol, dimana selisih skor pretest - posttest kelompok eksperimen lebih besar daripada kelompok kontrol. Hal ini menunjukkan bahwa model yang dikembangkan, berpengaruh secara signifikan untuk digunakan sebagai model pengembangan kompetensi guru SMK di Kabupaten Karanganyar Jawa Tengah.

\section{Tabel 2. Perkembangan Skor Uji Kompetensi Guru SMK di Kabupaten Karanganyar}

\begin{tabular}{llcccc} 
No. & Hasil & \multicolumn{2}{c}{ Kelompok Eksperimen } & \multicolumn{2}{c}{ Kelompok Kontrol } \\
& & Jumlah & Prosentase & Jumlah & Prosentase \\
\hline 1. & Meningkat & 25 & $100 \%$ & 21 & $84 \%$ \\
2. & Tetap & 0 & $0 \%$ & 0 & $0 \%$ \\
3. & Menurun & 0 & $0 \%$ & 4 & 16 \\
& Total & 25 & $100 \%$ & 25 & $100 \%$ \\
\hline
\end{tabular}

Skor uji kompetensi guru SMK apabila dinyatakan dalam sebuah grafik tampak seperti gambar 2 berikut.

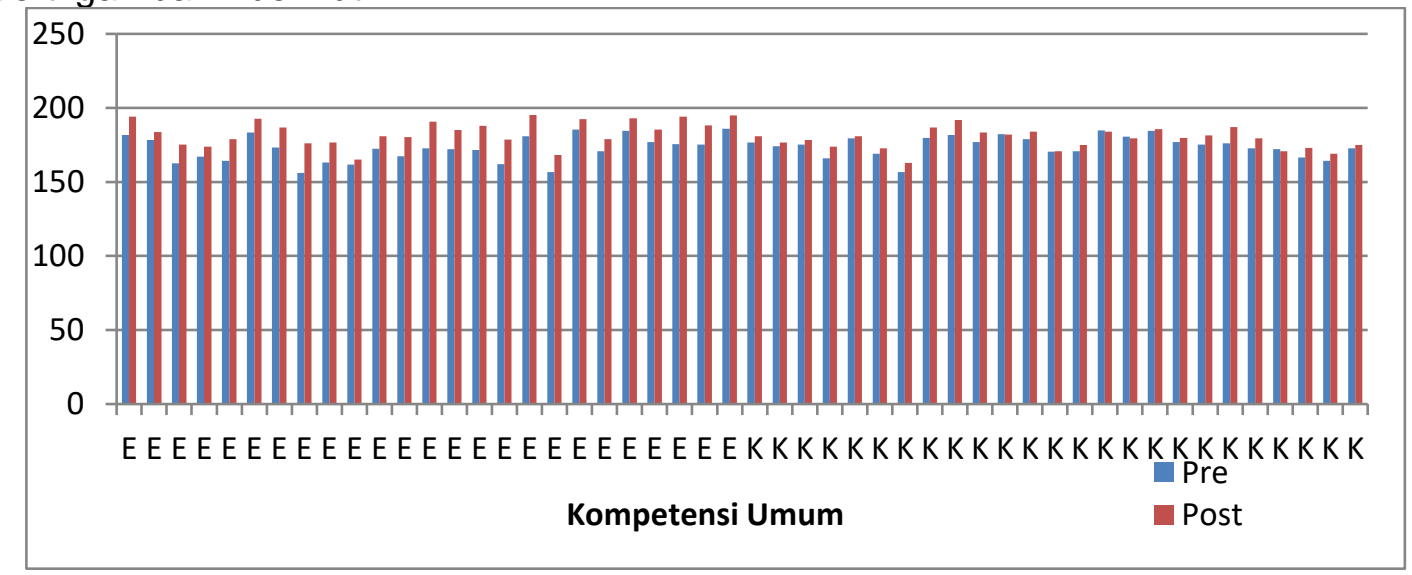

Gambar 2. Grafik Skor Uji Kompetensi Guru SMK Kabupaten Karanganyar 
SHEs: Conference Series 4 (3) (2021) $63-72$

Sumber: Data empiris yang telah diolah berikut.

Selanjutnya, pembahasan skor masing-masing kompetensi tersaji pada paparan 1. Kompetensi Pedagogik

Tabel 3. Perkembangan Skor Uji Kompetensi Pedagogik Guru SMK di Kabupaten Karanganyar

\begin{tabular}{cccccc} 
No. & Hasil & \multicolumn{2}{c}{ Kelompok Eksperimen } & \multicolumn{2}{c}{ Kelompok Kontrol } \\
& & Jumlah & Prosentase & Jumlah & Prosentase \\
\hline 1. & Meningkat & 25 & $100 \%$ & 15 & $60 \%$ \\
2. & Tetap & 0 & $0 \%$ & 2 & $8 \%$ \\
3. & Menurun & 0 & $0 \%$ & 8 & $32 \%$ \\
& Total & 25 & $100 \%$ & 25 & $100 \%$ \\
\hline
\end{tabular}

Tabel 3 merupakan perbandingan skor pre-test dan pos-test dari 50 responden yang dipilih sebagai subyek uji. Meskipun skor uji kompetensi pedagogik ada yang mengalami peningkatan, tetap, maupun penurunan namun rata-rata skor uji kompetensi pedagogik guru SMK di Kabupaten Karanganyar mengalami peningkatan.

Setelah dilakukan uji beda mean selisih skor pretest - postest dengan menggunakan uji t-test, diperoleh nilai t hitung sebesar 7,152 dan signifikansi sebesar 0,000. Oleh karena nilai $t$ hitung lebih besar dari nilai t tabel $(7,152>2,064)$ dan signifikansi $0,000<0,05$ maka Ho ditolak, sehingga disimpulkan terdapat perbedaan yang signifikan selisih skor pretest dengan skor poste

st kompetensi pedagogik antara kelompok eksperimen dengan kelompok kontrol. Hal ini menunjukkan bahwa model "ANAK SALA" yang dikembangkan, berpengaruh secara signifikan untuk digunakan sebagai model pengembangan kompetensi pedagogik guru SMK.

\section{Kompetensi Profesional}

Tabel 4. Perkembangan Skor Uji Kompetensi Profesional Guru SMK di Kabupaten Karanganyar

\begin{tabular}{cccccc} 
No. & Hasil & \multicolumn{2}{c}{ Kelompok Eksperimen } & \multicolumn{2}{c}{ Kelompok Kontrol } \\
& & Jumlah & Prosentase & Jumlah & Prosentase \\
\hline 1. & Meningkat & 22 & $88 \%$ & 21 & $84 \%$ \\
2. & Tetap & 0 & $0 \%$ & 1 & $4 \%$ \\
3. & Menurun & 3 & $12 \%$ & 3 & $12 \%$ \\
& Total & 25 & $100 \%$ & 25 & $100 \%$ \\
\hline
\end{tabular}

Meskipun skor uji kompetensi professional ada yang mengalami peningkatan, tetap, maupun penurunan namun rata-rata skor uji kompetensi profesional guru SMK di Kabupaten Karanganyar mengalami peningkatan. Setelah dilakukan uji beda mean selisih skor pretest - posttest dengan menggunakan uji t-test, diperoleh nilai t hitung sebesar 
3,833 dan signifikansi sebesar 0,000 . Oleh karena nilai $t$ hitung lebih besar dari nilai t tabel $(3,833>2,064)$ dan signifikansi $0,000<0,05$ maka Ho ditolak, sehingga disimpulkan terdapat perbedaan secara signifikan selisih skor pretest dengan skor posttest kompetensi profesional antara guru kelompok eksperimen dengan guru kelompok kontrol. Hal ini menunjukkan bahwa model "ANAK SALA" berpengaruh secara signifikan untuk digunakan sebagai model pengembangan kompetensi profesional guru SMK di Kabupaten Karanganyar Jawa Tengah.

\section{Kompetensi Kepribadian}

Tabel 5. Perkembangan Skor Uji Kompetensi Kepribadian Guru SMK di Kabupaten Karanganyar

\begin{tabular}{cccccc}
\hline No. & Hasil & \multicolumn{2}{c}{ Kelompok Eksperimen } & \multicolumn{2}{c}{ Kelompok Kontrol } \\
& & Jumlah & Prosentase & Jumlah & Prosentase \\
\hline 1. & Meningkat & 22 & $88 \%$ & 20 & $80 \%$ \\
2. & Tetap & 0 & $0 \%$ & 1 & $4 \%$ \\
3. & Menurun & 3 & $12 \%$ & 4 & $16 \%$ \\
& Total & 25 & $100 \%$ & 25 & $100 \%$ \\
\hline
\end{tabular}

Skor uji kompetensi kepribadian ada yang mengalami peningkatan, tetap, maupun penurunan namun rata-rata skor uji kompetensi kepribadian guru SMK di Kabupaten Karanganyar mengalami peningkatan. Setelah dilakukan uji beda mean selisih skor pretest - posttest menggunakan uji t-test, diperoleh nilai t hitung sebesar 1,372 dan signifikansi sebesar 0,177 . Oleh karena nilai t hitung lebih kecil dari nilai t tabel $(1,372<$ 2,064) dan harga signifikansi $0,177>0,05$, maka Ho diterima. Hal ini artinya tidak terdapat perbedaan secara signifikan selisih skor pretest dengan skor posttest kompetensi kepribadian antara kelompok eksperimen dengan kelompok kontrol. Namun, oleh karena secara bersama-sama terdapat perbedaan secara signifikan selisih skor pretest dengan skor posttest kompetensi guru antara kelompok eksperimen dengan kelompok kontrol, maka dapat disimpulkan bahwa model "ANAK SALA" yang dikembangkan berpengaruh secara signifikan untuk digunakan sebagai model pengembangan kompetensi kepribadian guru SMK di Kabupaten Karanganyar Jawa Tengah.

\section{Kompetensi Sosial}

Tabel 6. Perkembangan Skor Uji Luas Kompetensi Sosial Guru SMK di Kabupaten Karanganyar

\begin{tabular}{cccccc} 
No. & Hasil & \multicolumn{2}{c}{ Kelompok Eksperimen } & \multicolumn{2}{c}{ Kelompok Kontrol } \\
& & Jumlah & Prosentase & Jumlah & Prosentase \\
\hline 1. & Meningkat & 21 & $84 \%$ & 12 & $48 \%$ \\
2. & Tetap & 2 & $8 \%$ & 3 & $12 \%$ \\
3. & Menurun & 2 & $8 \%$ & 10 & $40 \%$ \\
& Total & 25 & $100 \%$ & 25 & $100 \%$ \\
\hline
\end{tabular}

Berdasar data tabel 6, skor uji kompetensi sosial guru SMK di Kabupaten Karanganyar ada yang mengalami peningkatan, tetap, maupun penurunan namun rata- 
SHEs: Conference Series 4 (3) (2021) $63-72$

rata skor mengalami peningkatan. Setelah dilakukan uji beda mean selisih pretest-posttest dengan menggunakan uji t-test, diperoleh nilai t hitung sebesar 2,733 dan signifikansi sebesar 0,009 . Oleh karena nilai t hitung lebih besar dari nilai t tabel $(2,733>2,064)$ dan harga signifikansi 0,009 $<0,05$, maka Ho ditolak. Hal ini berarti terdapat perbedaan secara signifikan selisih skor pretest dengan skor posttest kompetensi sosial antara kelompok eksperimen dengan kelompok kontrol. Jadi, dapat disimpulkan bahwa model "ANAK SALA" yang dikembangkan berpengaruh secara signifikan untuk digunakan sebagai model pengembangan kompetensi sosial guru SMK di Kabupaten Karanganyar Jawa Tengah.

\section{KESIMPULAN}

Secara efektif pengembangan kompetensi guru SMK di Kabupaten Karanganyar Jawa Tengah dapat dilakukan menggunakan model "ANAK SALA". Hal ini terbukti adanya peningkatan kompetensi guru SMK setelah dilakukan uji coba model pengembangan kompetensi guru SMK "ANAK SALA" ini, baik uji coba secara terbatas maupun secara luas. Lagi pula, setelah dilakukan uji beda mean (rerata) menggunakan uji t-test selisih skor pretest - posttest antara kelompok eksperimen dengan kelompok kontrol, secara statistik menunjukkan terdapat perbedaan yang signifikan selisih skor pretest dengan skor posttest antara kelompok eksperimen dengan kelompok kontrol, dimana selisih skor pretest - posttest kelompok eksperimen lebih besar daripada kelompok kontrol. 
SHEs: Conference Series 4 (3) (2021) $63-72$

\section{REFERENSI}

Ali, M. (2011). Psikologi Remaja Perkembangan Peserta Didik. PT Bumi Aksara.

Alqiawi, D. A., \& Ezzeldin, S. M. (2015). A Suggested Model for Developing and Assessing Competence of Prospective Teachers in Faculties of Education. World Journal of Education, 5(6), 65-73. https://doi.org/10.5430/wje.v5n6p65

Bhargava, A., \& Pathy, M. (2011). Perception of Student teachers about Teaching Competencies. American International Journal of ..., 1(1), 77-81. http://aijcrnet.com/journals/Vol._1_No.1_July_2011/10.pdf

Gall, M.D. \& Borg, W. R. (1983). Educational research an introduction. Longman.

Hermanto, R., \& Santika, S. (2016). Analisis hasil uji kompetensi guru matematika sekolah menengah pertama ( SMP ) di Kota Tasikmalaya. JP3M: Jurnal Penelitian Pendidikan Dan Pengajaran Matematika, 2(2), 135-142.

Spencer, M.L. \& Spencer, M. S. (1993). Competence at work: Models for superrior performance. John Wiley \& Son,Inc.

Sugiyono. (2012). Metode Penelitian Kuantitatif Kualitatif dan R\&B. Alfabeta.

Surya Dharma. (2013). Tantangan guru SMK abad 21. Direktorat Pembinaan Pendidik dan Tenaga Kependidikan Pendidikan Menegah Direktorat Jenderal Pendidikan Menegah Kementerian Pendidikan dan Kebudayaan.

Suyanto \& Asep Jihad. (2013). Menjadi guru profesional, strategi meningkatkan kualifikasi dan kualitas guru di era global. Esensi.

$\mathrm{Xu}, \mathrm{A}$. , \& Ye, L. (2014). Impacts of teachers' competency on job performance in research universities with industry characteristics: Taking academic atmosphere as moderator. Journal of Industrial Engineering and Management, 7(5), 1283-1292. https://doi.org/10.3926/jiem.1261 